\title{
Product Liability Reform from the Perspective of the Sporting Goods Manufacturer
}

\author{
Lori K. Miller and Lawrence W. Fielding \\ University of Louisville \\ Louisville, KY
}

The current product liability system is too complex and inefficient. Attempts at reform have been advanced since the early $1970 \mathrm{~s}$ when Congress first became alerted to the many problems both consumers and manufacturers faced in navigating the system. Six product liability reform bills have been presented to Congress since 1981. Philip K. Howard's recent best seller, The Death of Common Sense (1994) points out sever problems in product safety law and does the more highly publicized Contract with America (Gillespie and Schellhas, 1994). These recent works are merely additions to a call for reform voiced by American manufacturers since the late 1960s.

Proponents of reform argue that uniform legislation is necessary to bring about a more efficient and predictable product liability system (Product Liability Fairness Act, 1993). At the present time product liability lay varies amount the 50 states (Schloerb, Blatt, Hammesfahr, and Nugent, 1988). Product liability reform advocates believe that a uniform product liability law would resolve many of the inefficiencies and deficiencies within the current product liability system. As explained by Schwartz (1993, p. 270), "Products are uniform, and standards of and for safety should have uniformity." Schwartz believes that state-by-state product liability laws are inefficient since only $30 \%$ of all product manufactured are sold in the state in which a particular manufacturing company resides (Schwartz, 1993). Individual state legislation, therefore, only provides manufacturers with operating parameters and guidelines for $30 \%$ of its manufactured goods. Manufacturers, product sellers, insurers, and consumer-plaintiffs are all disadvantaged by this unpredictability in how liability will impact company operations and expenses.

Manufacturing companies are further hindered by the courts willingness to redistribute wealth from out-of-state manufacturers to in-state plaintiff(s). As Justice Richard Neeley, West VA Supreme Court of Appeals, testifies (Product Liability Fairness Act, 1993e), an in-state plaintiff, in-state (elected) judge, in-state jury, in-state witnesses, in-state spectators frequently are biased against the out-ofstate manufacturer. Manufacturers, on the other hand, are unable to contour product prices to individual state liability laws. Higher prices result as the pro-plaintiff 
product liability laws force manufacturers to cover potential liability loss (Hay, 1992).

Advocates of product liability reform argue that the expense associated with the current system hinders the ability of American companies to compete both domestically and globally. Transaction costs, insurance costs, punitive damages, delayed or eliminated research and development, and the expenses associated with unpredictability are all factors placing the U.S. companies at a competitive disadvantage. Many products are not brought to market due to the lack of demand associated with a premium price, the inability to get insured, or because of a foreign competitor's low cost production (Product Liability Reform Act, 1990). The manufacturers inability to compete on price curtails the manufacturing of goods which directly impact job development and the rate of employment.

The sporting goods industry has crusaded for product liability reform since the late $1960 \mathrm{~s}$. In fact, product liability reform has been the number one legislative concern of the SGMA (Product Liability Fairness Act, 1993a). In 1989, the Outdoor Recreation Coalition of America "made product liability reform its No. 1 priority" (Sanderfoot, 1989). In 1977, the Sporting Goods Manufacturers Association (SGMA) formed the Multi-Association Action committee as an ad hoc committee to lobby for product liability reform. The SGMA has been involved in Congressional hearings since 1977 and served as a "catalyst and clearinghouse to inform Congress and the Administration of our concerns" (Product Liability Reform Act, 1990, p. 595). The SGMA formed the Multi-Association Action Committee (MAAC) in 1977 which sought to:

1. Establish uniformity in the law;

2. Provide a realistic statute of limitations defining liability for aging equipment, including provisions for state of the art design and/or materials as a legitimate defense;

3. Reduce or cap punitive damage awards as a deterrent to future misconduct; and

4. Limit contingency fees to prevent attorneys from becoming partners of the injured parties (Product Liability Reform, 1982, P. 287).

The Coalition of Americans to Protect Sports (CAPS) was formed in 1986. CAPS strives to "inform coaches, schools, and the general public about the detrimental impact liability is having on manufacturers of sports equipment and programs across the United States" (Product Liability Reform Act, 1990, p. 595), The sport industry also banded together to form Product Liability Sports (PLS). As explained by Kotlowski (1988, p1), the goal of PLS is, "The preservation of American sports and recreation, which... has been threatened by imbalances in the civil justice system." SGMA recently formed the Sports Litigators Group. As explained by the SGMA in its testimony before the Subcommittee (Product Liability Reform Act, 1990 , p. 595), "This new advisory panel analyzes the impact of legislation on the sports industry and continues to serve as counsel to the association on the liability issue." As noted in the SGMA's testimony before the Subcommittee (Product Liability Reform Act, 1990, p. 597), manufacturers, retailers, and consumers of 
"trampolines, football helmets, lawn darts, pole vaulting pits,...rowing machines, institutional gym equipment, heavier stationary bikes, gravity machines, protective eye wear, and baseball and softball protective equipment" are all subject to the devastation of the product liability system.

This paper provides an analysis of the current product liability system and suggestions for reform from the perspective of sporting goods manufacturers. Part I of this paper review the evolution from contractual liability to enterprise liability. Part II elaborates on the current product liability system and related factors creating competitive disadvantages for American businesses. Part III discusses the recent Senate Bill 687 and how this bill attempted to curtail many of the problems associated with the U.S.'s current product liability system. Part IV presents the reader with a summary of the cogent issues and comments on how the new Congress will likely impact product liability reform efforts.

\section{THE EVOLUTION FROM CONTRACTUAL PRODUCT LLABILITY TO ENTERPRISE LIABILITY}

Privity of contract is a time-honored concept the United States' courts adopted from England's judicial system (Winterbottom v. Wright, 1842). The privity of contract requirement provided recourse to an injured plaintiff when a manufacturer breached a contractual warranty. However, recourse was contingent upon a direct relationship between the product manufacturer and the end user. The end user's ability to recover for product injuries was not problematic during the agrarian or preindustrial ear when consumers typically entered into direct consumer transactions, or exchanges, with a local manufacturer. As explained by Justice Francis in the Henningsen v. Bloomfield Motors, Inc., case (1960),

Marketing conditions were simple,... maker and buyer frequently met face to face on an equal bargaining plane and many of the products were relatively uncomplicated and conducive to inspection by a buyer competent to evaluate their quality (p.80).

Urbanization and the beginnings of a capitalistic, industrialized society extended the use of wholesalers and independent distributors. This development of the distributive trade altered the recourse available to the end user (Jeanblanc, 1937; Kessler, 1943; Traynor, 1965). As explained by Jeanblanc (1937),

With the intervention of middlemen the consumer was no longer in privity of contract with the maker of the goods, and the system of warranties, which therefore had afforded him adequate protection, was rendered ineffective (p. 134).

Legal scholars have suggested that the burgeoned use of middlemen (e.g., independent wholesalers, jobbers) exemplified a conscious intent by manufacturers to decrease potential product liability as well as decrease cost of product distribution. Manufacturer's were well aware that the independent distributor, not the end user, met the privity of contract requirement (MacPherson v. Buick, 1916). As explained by Judge Francis in Henningsen v. Bloomfield Motors, Inc. (1960), the use of independent distributors allowed manufacturers to place a "buyer" between the 
manufacturer and the end user; eliminating the end user's ability to have a contractual relationship with the manufacturer. The problem, as argued by consumer advocates like Ralph Nader (1972), is that manufacturers would induce purchases via mass marketing. consumers, persuaded by businesses marketing tactics, would then purchase desired products. Unfortunately, the end user sustaining product-related injuries was left powerless and unable to seek legal recourse against the manufacturer. The use of the independent distributors forced consumers to accept demanded products on a caveat emptor basis.

Consumer advocates further argued that evolution of an increasingly commercialized society allowed manufacturers to further abuse the consumer via the use of standardized contracts. Manufacturers, striving to decrease potential liability, construed contracts and related warranties in their best interest. For example, manufacturers frequently used (and continue to use) limited duration warranties and disclaimed all implied warranties (Priest, 1985). The consumer, not even being a party to the contract, had no power to bargain over the terms and conditions of the contract itself. The privity of contract requirement allowed manufacturers, who distributed through middlemen, the latitude to interpret contracts and related warranties in ways that suited their own interest.

Courts, regardless of the alleged inequities, upheld precedent and sanctified the privity of contract requirement as legal and binding (Kessler, 1943; Printing and Numerical Registering Co. v. Sampson, 1875). As explained by Kessler, Here lies the main obstacle to progress... (courts) prefer to convince themselves and the community that legal certainty and "sound principles" of contract law should not be sacrificed to dictates of justice or social desirability (p. 637).

Similarly, Priest stated (1985, p. 487),

The role of the principle of freedom of contract in the development of Western economies, however, had completely transformed. Though in the eighteenth century the principle of freedom of contract had introduced an unprecedented scope of individual liberty, in the modern world it had become an instrument of coercion.

Plaintiff attorneys attempted to circumvent, and dilute the harshness of, the privity of contract requirement which effectively absolved the manufacturer of all liability. Plaintiff attorneys sought recovery by arguing that the res ipsa loquitor doctrine, the last clear chance rule, negligence, and/or the "dangerous instrumentality" doctrine imposed liability on the manufacturer.

The Court of Appeals of New York, in the 1916 landmark case of MacPherson $v$.

Buick, was viewed as a victory for the plaintiff and other consumer advocates. Judge Cardoza recognized the ability of the consumer to recover damages absent any contractual relationship with the manufacturer. As stated by Judge Cardoza, The dealer was indeed the one person of whom it might be said with some approach to certainty that by him the car would not be used. Yet the defendant would have us say that he was the one person whom it was under a legal duty to protect. The law does not lead us to so inconsequent a conclusion (p. 442).

Judge Cardoza's opinion was somewhat revolutionary in the area of products 
liability. The negligence doctrine was applied by only a paucity of courts for the following four decades. More important, Cardoza's notion about judge as law maker and architect of social justice found its way in to judicial thinking where it would be applied to product liability in the 1960s (White, 1985). But, until the 1960s courts were repetitively reluctant to sabotage the established sanctity associated with the freedom to contract. In addition, courts continued to respect the precedent established in Winterbottom $v$. Wright (1842). The English court and subsequent American courts feared a flood of cases should the privity of contract be abandoned. As stated by Lord Abinger in Winterbottom v. Wright (1842), "Unless we confine the operation of such contracts as this to the parties who entered into them, the most absurd and outrageous consequences, to which I can see no limit, would ensue." (p. 405).

Despite such concerns, the judiciary gradually evolved to become the champion of consumer rights. The justice pendulum swung away from the manufacturer and became fastened on the side of the consumer. Landmark decisions between 1960 and 1964 brought an end to the privity of contract requirement and solidified the pro-plaintiff movement in product liability litigation. Henningsen v. Bloomfield Motors, Inc. (1960) was the beginning of this revolution in product liability (Priest, 1985; Prosser, 1966). In the Henningsen case, Judge Francis argued that sound social policy demanded the demise of the privity of contract requirement. As explained by Judge Francis, sales laws and related warranties were adopted to protect the consumer. The manufacturer's ability to circumvent responsibility via the establishment of independent distributors was socially unjust. "The obligation of manufacturers," he stated, "should not be based alone on privity of contract" (Henningsen v. Bloomfield, 1960, p.83). Instead, he argued, "It should rest, as was once said, upon the demands of social justice" (Henningsen v. Bloomfield, 1960, p. 83). The Henningsen case (1960) echoed the socially just concept of risk distribution inbred within worker compensation statutes. Risk distribution advocates argue that it is better to spread losses among society than to invoke a substantial loss on one individual who is unable to pay. As expounded by this theory, businesses are in an ideal position to distribute resultant loss via higher prices or insurance. Justice Traynor, writing a concurring opinion with exceptions, states in Escola v. CocaCola Bottling Company (1944),

It is evident that the manufacturer can anticipate some hazards and guard against the recurrence of others, as the public cannot. Those who suffer injury from defective products are unprepared to meet its consequences. The cost of injury and the loss of time or health may be an overwhelming misfortune to the person injured, and a needless one, for the risk of the injury can be insured by the manufacturer and distributed among the public as a cost of doing business (p. 441).

Legal scholars and consumer advocates further argue that business's cognizance of possible loss would make them more safety-oriented and willing to upgrade quality control practices (Garret, 1972; Nader, 1972; Plant, 1967).

The Henningsen case also criticized the privity of contract relationship as being unjust. Even if there was a contractual relationship, Judge Francis explained, the 
contract was not a negotiated instrument. Rather, the manufacturer stipulated the contractual terms in its own best interests. The mass marketing practices of manufacturers created a demand for products. Consumers, desiring products, willingly purchased the products regardless of the contractual terms. Again, Judge Francis argued that the existence of a contractual relationship between the manufacturer and the end-user was irrelevant based upon established principles of social justice.

Judge Traynor's 1962 California Supreme Court decision in Greenman v. Yuba Power Products expressed the sentiments of the earlier, non-precedent MacPherson decision (1916) and held the manufacturer liable for a negligently designed product (Cantu, 1993; Priest, 1985; Prosser, 1966). As explained by Judge Traynor in Greenman (1962),

The purpose of such liability is to insure that the costs of injuries resulting from defective products are borne by the manufacturers that put such products on the market rather than by the injured persons who are powerless to protect themselves. Sales warranties serve this purpose fitfully at best (p. 900).

Traynor's opinion in Greenman was a logical application of the theory of strict liability established by Traynor in Escola v. Coca-Cola Bottling Co. (1944). In Escola (1944), Traynor proposed two main tenets that would become standard concepts in social justice theory. First, he argued,

Public policy demand that responsibility by fixed wherever it will most effectively reduce the hazards to life and health inherent in defective products that reach the market (p. 462).

Second, Traynor argued, "The risk of injury can be insured by the manufacturer and distributed among the public as a cost of doing business" (p. 462). Traynor's Greenman (1962) opinion echoed these sentiments as well as concepts established in the MacPherson case (1916) and The Law of Torts( Prosser, 1941). Unlike the earlier MacPherson case (1916), the 1962 Greenman Case set a precedent immediately copied by a vast number of other courts.

Prosser, responsible for Section 402A of the Second Restatement of Torts, further solidified the low of enterprise liability in 1964 and authorized the era of "plaintiff-oriented litigation" (Cantu, 1993, p. 328). As stated by Prosser in Section $402 \mathrm{~A}$, a seller (i.e., manufacturer) is liable if an "unreasonably" dangerous or defective product causes injury. Section 402A(2) imposed liability on a seller even though the seller "exercised all possible care in the preparation and sale of his product." This made the defendant manufacturer strictly liable. As stated by Cantu (1993, p. 345), "Any argument that the defendant acted as a reasonable, prudent person is totally irrelevant." Section $402(\mathrm{~A})(2)(\mathrm{b})$ further nullified the privity of contract requirement by stating that the seller was liable in the above situation regardless of an existing contractual relationship between the consumer and seller. As explained by Bruns, "The doctrine of strict liability is being interpreted to mean a manufacturer's product no longer needs to be at fault to be guilty, but simply needs to be involved in an accident" (Product Liability Insurance, 1977c, p. 413).

By 1964 , the concept of enterprise liability (i.e., strict liability) dominated 
judicial outcomes. Product liability decisions were no longer based upon the cavalier, caveat emptor approach. Instead, as explained by Priest (1985, p. 470), product liability litigation focused not on "the resolution of disputes, rule definition, or the expression of moral values, but compensation of the injured." Compensation of the injured meant that someone had to pay. Social justice ideology conspired with court opinion to target the manufacture. Priest (1985, p. 476) describes the legal transition to social justice as follows, "Fault-based focus of a rule was a feature of medieval times and... the modern direction of the law was toward liability without fault." Judicial decision making had become what Cardoza proposed in MacPherson (1916) responsive to contemporary problems and conditions. In addition, judicial decision making had become responsive to public attitudes and public demands (White, 1985). As stated by Goldman (1976), quoting Yankelovich,

We in this nation have with increasing force tended to regard every legitimate want that an individual may feel as being a need, and every need as an individual right which our society can and must fulfill (p. 52).

The fear of mass litigation expressed in the 19 th and early 20 th century was accurate. As noted in Dunworth (1988), the number of product liability federal filings increased $733 \%$ between 1974 and a 1986 . In comparison, non-product liability federal filings increased only $26.2 \%$ during this same time period.

The sporting goods industry became acutely aware of the litigation problems in the late 1960s. Robert Brown of Rawlings Sporting Goods warned members in 1969 of the Athletic Goods Manufacturing Association (AGMA) about a "new type of ambulance chaser, lawyers sniffing lawsuits..." (Burke, 1969a). The New Jersey supreme court's decision in O'Brien v. Muskin Corporation (1983) illustrates the hardships strict liability imposed on sporting goods manufacturers. In the O'Brien case, a 23 year old plaintiff was seriously injured when he dove into an outdoor, above ground swimming pool with an embossed vinyl liner. The plaintiff alleged that the manufacturer was strictly liable for failure to warn and for using the vinyl liner. There was a warning on the pool which stated, "DO NOT DIVE" in 1.5" letters. The plaintiff's expert witness testified that he knew of no other type of lining, other than vinyl, used in above ground swimming pools. The New Jersey supreme court remanded the question of whether the use of vinyl lining consisted of a design defect. As stated by the O'Brien court (1983), "Even if there are no alternative methods of making bottoms for above -ground pools, the jury might have found that the risk posed by the pool outweighed its utility" (p. 306). The precedent set by this case is dangerous. As explained by Twerski (1985),

Courts may rely on $O^{\prime} B r i e n$ to declare defective in design a product used in millions of American homes even though the manufacturer provides adequate warning of the risks involved in its misuse and the plaintiff fails to present any evidence of an alternative design that would render the product safer (p.588).

As reflected in the $O$ 'Brien case, strict liability eliminated the manufacturer's use of traditional product liability defenses (e.g., product misuse, alteration) and absolved the consumer of any responsibility for injuries. Rather, manufacturers became a provider of social insurance. As stated by William B. Ruger, Sr. President 
and Chairman of the board of Sturm, Ruger \& Co., Inc. (a firearm manufacturer), "Tort law is not a compensation system similar to social security or workers compensation" (Product Liability Legislative Hearing, 1980, p.543)

\section{The fallacies associated with risk distribution from the perspective of the sporting goods industry}

Enterprise liability imposes particular hardships on the sporting goods industry. Sport inspires activity, often aggressive activity, in comparison to other leisure activities such as reading or shipping. Activity itself invites injury. Enterprise liability invites lawsuits against manufacturers regardless of fault. As reported in the Sporting Goods Dealer, a survey of SGMA members revealed that $78 \%$ of them had been involved in litigation (Goldman, 1976b). Members of the sporting goods industry concluded early in 1976 that the risks associated with enterprise liability would force many sporting goods businesses to forfeit operations (Goldman, 1976a).

There are four primary misnomers associated with the concept of enterprise liability and the related notion of risk distribution. First, liability based upon fault encourages, if not forces, manufacturers to both provide a safe product and be held liable when engaged in negligent activity. Manufacturers, and sporting goods manufacturers in particular, agree that end users should be able to recover when injured by a product which was defectively designed, constructed, or when the manufacturer failed to adequately warn about a particular product. However, sporting goods manufacturers oppose being held liable simply because society perceives the company as having "deep pockets." As explained in 1980 by Tom Anderson, a representative of the Bicycle Manufacturing Association,

It is obvious that bicycles are not built to carry five people, that a light-weight tenspeed should not be used on a bicycle motor cross trail, and that bicycles should not be towed by cars. A manufacturer should not be liable for injuries caused by this type of use (Product Liability, 1980a, p. 583).

Second, enterprise liability is not necessary in order to induce sport businesses to manufacturer safely and responsibly. Manufacturers fully recognize the public relations crisis resulting when company products inflict consumer injuries. As explained by Plant (1957, p.945).

What is probably a more powerful incentive to make products as safe as possible lies in the desire of manufacturers to avoid the danger that their products will develop a reputation for being unsafe or defective and therefore be unacceptable to the purchasing public.... The element which is most disturbing to manufacturers is not the potential judgment of legal liability but the injury which is done to the reputation of the product and its producer.

Manufacturers, attempting to avoid the dilution of any established goodwill, willingly implement policies and procedures (i.e., inspections, research and development) that contribute to the manufacturer of safe products.

Third, with the exception of select monopolies, most businesses are not in a position to internalize the loss. The sporting goods manufacturing industry, for 
example, is comprised of mid- to small-sized companies struggling to maintain market share. Sporting goods companies, in addition to non-sport businesses, forced to increase prices often became victims of bankruptcy (Ellis, 1982; Product liability Fairness Act, 1993a; Plant, 1957). Goldman (1976b) refers to testimony by Bob Bevenour (Executive Vice President of Nissen, a gymnastics manufacturing company) in the Sporting Goods Dealer. As stated by Bevenour,

It is virtually impossible to pass along $\$ 600,000$ to $\$ 700,000$ in insurance costs to customers. The sporting goods industry is too competitive to allow that. (Goldman, 1976b, p. 51)

Nimmons (CEO and President of Schutt manufacturing company) explained the exit of football helmet companies to the Senate Subcommittee in 1993. As explained by Nimmons,

Many of the companies that left the business never suffered an adverse judgment. They simply made a business decision that an irrational legal system left their companies with an unreasonable liability exposure. They were faced with potentially huge costs that they could not control, regardless of the safety or quality of their products. (Product Liability, 1993a, p. 20)

Fourth, the concept of enterprise liability, or risk distribution, contradicts the purpose of imposing punitive damages. Punitive damages are intended to punish the wrongdoer; make an example out of someone's tortuous conduct. There are two fallacies associated with enterprise liability and the awarding of punitive damages. First, the manufacturer may not even be a tortfeasor. Rather, the manufacturer if forced to pay punitive damages simply because of social mandate. Second, according to the risk distribution theory, punitive damages "spread punishment among large numbers of nonwrongdoers who do not deserve punishment and weaken the deterrent effect of damage assessments" (Ellis, 1982, p. 65). Punitive damages create a hardship for the company as well as the end-user via higher prices.

\section{- Factors creating competitive disadvantages for American sporting goods manufacturers}

The United State's current product liability system has placed American businesses, and the sporting goods industry in particular, at a competitive disadvantage. The current product liability system has subjected American businesses to escalating transaction costs and insurance dilemmas. The current product liability system has also forced companies to discontinue and/or delay research and development, stifle product innovation and modification, and remove high demand products from the market. The resultant implications have hindered economic development, product availability, and employment. Factors within the current product liability system which create a competitive disadvantage for sporting goods manufacturers are discussed in the following paragraphs.

\section{A. TRANSACTION COSTS}

Transaction costs include plaintiff's attorney fees, legal defense expenses, expert witness fees, settlement negotiations, staff support fees, and related fees 
associated with product liability litigation. A number of scholars have noted the exorbitant expense associated with transactions costs. Huber and Litan (1991) estimate that between $20 \%-50 \%$ of every claimant's dollar is used for transactionrelated activities. other studies (Kakalik and Pace, 1986; Schotter and Ordover, 1986) indicate that approximately $50 \%$ of all settlements are paid to lawyers and insurers. Senator Kasten reported during his testimony before the Subcommittee on Commerce, Consumer Protection, and Competitiveness that lawyers receive between 66-75\% of every dollar awarded (Product Liability Part 2, 1987). The National Machine Tool Builders' Association referred to an Insurance Service Office study which indicated that "for every 6 paid out to claimants by insurance companies for product liability, another $\$ 7$ is paid for lawyers and other transaction costs" (Product Liability Part 2, p. 37). The exorbitant transaction costs can be attributed to lengthy trial processes, the use of junk science, and America's contingency fee system.

The competitive disadvantage associated with transaction costs is illustrated in Figure 1. Transaction costs force sporting goods manufacturers to increase product prices. The law of supply and demand, however, illustrates that an increase in product prices will result in a decrease in product demand. Consequently, American companies lose market share to foreign competitors. Higher prices and declining market share eventually decrease profit margins below break-even levels. Companies operating at a loss are eventually forced to cease operations. The entire American economy suffers as jobs are lost, industries become extinct, and significant taxes monies are no longer generated. As noted above, reform advocates argue that America's contingency fee system, junk science, and lengthy trial periods are responsible for exorbitant transaction costs.

\section{B. INSURANCE COSTS}

Like transaction costs, escalating insurance expenses have had a traumatic effect on manufacturers. As stated in Senator Pressler's testimony (Product Liability Fairness Act, 1993, p. 111), "The cost of product liability insurance is 15 times higher in this country than it is in Japan, and 20 times higher than it is in Europe." A 1988 Conference Board report concluded that American manufacturers often pay between 20 and 50 times more for product liability insurance than foreign competitors (Litan, 1991). Further, insurance companies are reluctant to discount premiums when companies export products due to the possibility of a product liability lawsuit being filed in the American courts applying American product liability law (Product Liability Act, 1984). Unfortunately, foreign imports place American manufacturing companies at a cost disadvantage due to the lower product liability insurance rates in foreign countries and their more consistent, efficient product liability laws.

America's insurance costs have increased markedly. The Product Liability Reform Act (1993) cited a study by the American law Institute (ALI) that reported a 44\% increase in liability insurance costs between 1950 and 1980 . In comparison, the GNP increased only .26\% during this same time period. Florio (1983) reported that some product sellers experienced premium increases of $300 \%$ while others 
were unable to secure coverage at any price (p. 3). Priest (1987) stated that in some cases insurance has increased by as much as $1500 \%$. The insurance industry blamed the escalating costs on the unpredictability associated with the current product liability system. Maxfield (1982) argued that the instability of the tort system prompted insurance companies to engage in "panic pricing." The instability was created by the fact that the product liability tort system was a state by state system. Insurance underwriters were national. They had great difficulty in predicting liability premiums because they had to deal with 50 different sets of state laws (Product Liability Act, 1985). Frank Swain, Chief Counsel for Advocacy of the United States Small Business Administration, pinpointed what he thought was the problem for members of the House subcommittee on Commerce, Consumer Protection, and Competitiveness, in 1987 (Product Liability, 1987a). Swain stated,

In my opinion a Federal product liability standard is needed to provide some consistency to widely divergent state laws. Because a product manufacture in one state is typically sold to sellers and consumers in many states, it is never known at the onset which state's product liability law will apply in the event of an injury. The patchwork of differing state laws creates uncertainty which is reflected in higher liability insurance rates and, ultimately, consumer price (p. 379).

Contentious manufacturers prompted the federal government to intervene. The government established the Federal Interagency Task Force on Product Liability in 1976 to investigate the insurance crisis. The Federal Interagency Task Force on Product Liability concluded that the inefficiencies existing within America's current product liability system influenced the ambiguous and excessive insurance premiums. Dennison, Director of the SGMA Washington operations, told a Senate Subcommittee, "Many manufacturers are finding themselves not being able to renew insurance coverage. The reason for this precarious situation is the strict liability system" (Product Liability Act, 1985, p. 192). For Paul Benke (Product Liability Insurance, 1977a) the real cause was the "... ease with which judgments are rendered against defendant manufacturers and because of a few well publicized large judgments." In 1981 insurance companies paid $\$ 13.8$ million in jury awards and another $\$ 3$ million for out-of-court settlements to plaintiffs injured by football helmets (Product Liability Act Amendments, 1985). By 1985, suits against football manufacturers totaled \$110 million (Product Liability Act, 1985).

The insurance crisis impacted municipalities as well as for-profit operations (Priest, 1987). For example, government entities such as park and recreation departments and universities encountered extreme insurance premiums between 1980 and 1985. A report by the Department of Justice indicted a $141 \%$ increase in claims against municipalities during the early 1980s (Priest, 1987). The problem associated with the insurance phenomena, as explained by Benke during the 1977 product liability hearings,

Insurance premiums are not based primarily on what has happened in the pastsuch as a company having no product liability claims - but rather are based on the insurance company's guess as to what will happen in the future (Product Liability Insurance, 1977a, p. 92). 
As illustrated above, the underwriting policies of insurance companies raised havoc in the sporting goods industry. The product liability crisis discouraged insurance companies from insuring risk-oriented endeavors or those endeavors (e.g., products, activities) which were injury prone (e.g., football helmet manufacturers, trampolines, diving boards) (Priest, 1987). New entrants into the sporting goods industry were especially hard hit. Manufacturing companies unable to get insurance found that many retail stores (e.g. Hermans) were unwilling to carry uninsured products (Goulian, 1988). Municipalities, manufacturers and retailers unable to get adequate insurance were often forced with four dismal alternatives: 1) manufacturers could self-insure; 2) drop specific products or sport activities that insurance companies considered dangerous; 3) cease production and close business operations; 4) move manufacturing operations to foreign countries.

First, manufacturers could decide to self-insure. Self-insurance, however, became synonymous with non-insurance as small sporting goods manufacturers did not generate the revenues necessary for the establishment of an insurance reserve. Self-, or non-insurance, was problematic for both the manufacturer and the enduser. From the manufacturer's perspective, the damages associate with one lawsuit would bring about the demise of a company. Further, end-users injured by defectively designed or constructed products had no opportunity for recourse.

The SGMA's testimony referred to a number of companies which had been forced to operated without insurance due to the expense and/or unwillingness of insurance companies to provide services (Product Liability Insurance, 1977). A 1976 Sporting Goods Representatives Association survey revealed that $62 \%$ of manufacturers and field representatives were not covered by liability insurance (Goldman, 1976b). However, rather than create an internal "insurance" fund, or a fund for potential losses, companies found it more practical to simply go without insurance. Low profitability, the need for working capital, and tax disadvantages prompted many companies to operate without insurance (Product Liability Act, 1985; Product Liability Insurance, 1977).

The Product Liability Risk Retention Act of 1981 was designed to further alleviate the insurance crisis encountered by small businesses. As explained by Florio (1983),

Under the Act, product manufacturers are authorized to self-insure through insurance cooperatives called risk retention groups or to purchase insurance on a group basis... It was also hoped that competitive pressure from the new groups would encourage reform of insurance industry practices (p.5).

However, the Risk Retention Act benefited the sporting goods industry marginally, if at all. Even conglomerates like the Boat Industry Association (BIA) could not obtain liability coverage. Members of the BIA submitted detailed reports attesting to their fine safety record and their minimal claims history, but no insurance company in America would agree to underwrite a policy for them (Product Liability Insurance, 1977). Members of the Bicycle Manufacturers Association encountered similar hesitancies. For example, three out of the four bicycle manufacturing members could not obtain satisfactory liability insurance (Product Liability, 1980a). As explained by Dennison during the 1985 Product Liability Act Hearings, 
We have been told by the insurance industry that the sporting goods industry has been placed on the prohibited list. Because of the present liability system, insurance companies have made the determination that the exposure of sporting goods companies is too great for them to continue to assume (p. 193).

A second alternative for sporting goods manufacturers was to drop specific activities or products. This alternative is unattractive as the end-user has increased difficulty in accessing beneficial sporting opportunities. Further, the loss of generated revenues associated with the manufacture or hosting of a particular activity negatively impacted employment opportunities and generated taxes. The following anecdotes exemplify the adoption of this tactic as a way to reduce loss associated with the current product liability system.

YMCAs in Rhode Island eliminated diving boards from their pools (Castle, 1989).

Public parks chose to remove playground equipment and $90 \%$ of the nation's public swimming pools removed diving boards (Dart, 1989; Priest, 1987).

New Jersey prohibits skating on public ponds and lowa has banned pole vaulting from all public schools (Everett, 1989).

The State of Illinois removed trampolines from competition in 1977, copy a trend set in New Jersey, Kansas, Minnesota, Kentucky, Tennessee, Indiana, Nebraska, and lowa (Product Liability Insurance, 1977b).

Wilson, Spalding, and Wilson stopped the production of football helmets because liability insurance costs were too high (Product Liability Fairness Act, 1993a). They were soon followed by MacGregor, Gladiator, Kendall Company, Protective Products Division of Dickensen and Company and Southern Athletic Company.

A third alternative for sporting goods manufacturers was to simply cease production and close manufacturing operations. The loss of jobs and related taxes dilutes the attraction of this alternative. Further, there has been great concern as to whether the current product liability crisis would bring about the extinction of sport. Concerned stakeholders questioned whether sport would survive without the availability of sport implements and products (e.g., baseball bats, trampolines, diving boards) and related protective equipment (e.g., football helmets). For example, the current product liability system, as evidenced below, has contributed to the demise of a number of sporting goods manufacturing companies.

The Sierra Club, a non-profit rock climbing club, was forced into extinction when it realized a $140 \%$ increase in insurance costs although the number of rock climbing injuries remained unchanged (McHugh, 1989).

A kayak manufacturer reluctantly sold his company when his insurance premiums exceeded net income (Castle, 1989).

Marrietta Helmet Manufacturing company was forced into bankruptcy in 1976 because insurance costs were too high (Product Liability Insurance, 1977b).

Protective Products and Royal Manufacturing liquidated a year later because of unaffordable insurance costs. Neither company had ever been sued (Juer, 1977) 
As explained in the SGMA's testimony before the Subcommittee (Product Liability Reform Act, 1990, p. 596), "In December, 1988, the oldest archery company in the U.S. located in Middlebury, Connecticut dissolved after 76 years of business."

As summarized by Nimmons (Product Liability Fairness Act, 1993a),

Product manufacturers are seen as the insurers of last resort for sports activities. What that ultimately may mean is less access to sports, which would yet be another manifestation of the cost of product liability in our society (p.21).

The fourth alternative was for sporting goods manufacturing companies to relocate to another country with a more favorable product liability system. Again, this option imposes significant disadvantages on the American economy (e.g., jobs, taxes, discretionary income).

\section{DISCONTINUED AND/OR DELAYED RESEARCH AND DEVELOPMENT}

R\&D and its association with competitiveness is well documented. Research and development enables a firm to secure patents and continually develop new product features, extensions, and components. However, our current product liability system discourages research and development and hinders America's progressiveness, job opportunities, product availability. For example, the number of patents granted to Japanese companies increased $180 \%$ between 1975 and 1986 . In comparison, the number of patents secured by American companies, during the same time period, decreased 18\% (Litan, 1991).

The current product liability system discourages R $\& D$ efforts of manufacturing companies for two reasons. First, the transaction and insurance costs associated with the current product liability system (discussed above) usurp monies otherwise available for R\&D. During hearing $s$ on the product Liability Fairness Act the National Machine Tool Builders Association which stated that "its members spend seven times more on product liability costs than on research and development" (Product Liability Fairness, 1993, pp. 225-226). The expense associated with the current product liability system places American companies' research and development progressive efforts far behind their foreign competitors. Litan's (1991) work echoes this sentiment. Second, companies fear that new products, newly discovered information or safety measures will be used against them in court (Fox, 1988). senator Lieberman (Democrat, Conn.) echoed this sentiment in a statement at the 1993 Senate Subcommittee Hearings on product liability (Product Liability Fairness Act, 1993b). In his opening remarks Lieberman noted,

The evidence continues to mount that product liability considerations are stifling innovation and product development... The problem is that our product liability system can penalize manufacturers who spend the research and development time and resources to push the state of the art to solve old problems. New developments can often be used as evidence that old products were somehow defective (Product Liability Fairness Act, 1993b, pp. 2-3).

L. Vincent, Chairman and CEO of Biogen, Inc., expressed the sentiments of many 
American CEOs when he provided the 1993 Subcommittee with the following statement,

I am not prepared to bet the future of Biogen on the random lottery of the American product liability system. I myself have made the strategic decision not to pursue the development of an AIDS vaccine in the current environment because I have made a business judgment that there is a significant likelihood that the courts would bankrupt the company by awarding large judgments to sympathetic plaintiffs regardless of whether the vaccine actually caused the injury (Product Liability Fairness Act, 1993c, pp. 112-113).

Castle (1989, p. E2) recalls a manufacturer of skin diving snorkels who forfeited the introduction of a new improved snorkel because the insurers feared that the new unit will imply that "there was something wrong, perhaps dangerous, about the previous snorkels." As stated by Senator Gorton during the 1993 Senate hearings (quoting a Rand Corporation study),

Numerical simulation suggests that liability can substantially decrease incentive to innovate in product areas of which large liability costs seem plausible or financial disaster from liability is believed to be even a slight possibility (Product Liability Fairness Act, 1993d, p. 48).

Judge Richard Neeley believed that the threat of liability suits forced prudent companies to develop and test new products offshore (Product Liability Fairness Act, 1993e). Consequently, skilled and unskilled laborers lost jobs while states lost tax monies. The implication of reduced R\&D on American competitiveness is apparent. As explained by management guru Michael Porter, success and competitive advantage can only be achieved through innovation and sustained through relentless improvement (Product Liability Reform Act, 1990).

\section{INADEQUATE SUPPLIES DUE TO SUPPLIER CONCERNS}

The current product liability system impedes product innovation and modification as suppliers frequently decide not to supply needed components to riskrelated products. This is a problem for manufacturers seeking to purchase either domestic or foreign supplies. As explained by Nutter (1988),

One of the problems faced by U.S. businesses wishing to use foreign parts is that foreign manufacturers may not introduce products or may remove them from the U.S. markets because of U.S. liability concerns (p. 33).

Many U.S. manufacturers have persuaded foreign suppliers to supply the needed parts only by agreeing to bear the cost of all product liability litigation levied against foreign suppliers (Nutter, 1988).

Nimmons testified that the Schutt Sport Group was recently forced to abandon the introduction of both a new baseball product and an improved football helmet design because the suppliers did not want to be linked to the possible lawsuits. As explained by Nimmons (Product Liability Fairness Act, 1993a, P. 50),

It is the fear of being involved in litigation. As you look at the expense of defense in its entirety, even though they would be found not to be a contributing factor to an injury, it is just the point of being involved. Any time a product liability lawsuit comes through the door, the cost does escalate. 
Once again, the manufacturer forfeits the opportunity to supply a desired product to end-users.

\section{- Senate Bill 687 - Another effort to reform product liability}

Senate Bill 687, the product Liability Fairness act of 1993, was the culmination of a 17 year effort to establish a uniform product liability law. Senator Rockefeller introduced Senate Bill 687. The bill was also cosponsored by Senators Gorton, Danforth, Dodd, and Lieberman. Similar to other proposed product liability uniform legislation, the bill was defeated.

Senate Bill 687 addressed the limitations of intrastate product liability regulation. Seven sections of the bill provide remedies for problems that exist in the current product liability system. Each section is elaborated on in the following paragraphs.

\section{EXPEDITED CLAIM SETTLEMENTS}

The current product liability system has been extensively criticized for the time required to compensate injured victims. A survey by the Alliance of American Insurers reported that $21.6 \%$ of all claimants waited in excess of five years for payment. Maria Dennison stated that an injured athlete often waits 8 years before a case is decided (Product Liability Reform, 1982a). The Alliance of American Insurers report indicated that only $2.1 \%$ of all claimants were paid within a year after reporting their injury. Lengthy trial periods, common in the current product liability system, force seriously injured individuals to accept inadequate settlements in order to begin paying medical bills (Congressional Record, March 31, 1993, p. S4145).

Senate Bill 687 addresses the problems of delay and inequity resulting from the current product liability system by encouraging parties to submit and agree to outof-court settlements. As explained in the bill, defendants are subjected to a monetary penalty if they refuse to accept a plaintiff's settlement offer and then lose subsequent litigation. Specifically, defendants would be liable for the awarded damages in addition to a $\$ 50,000$ maximum payment for the plaintiff's attorney fees if the defendant refuses to settle and the court awards and amount equal to or greater than the plaintiff's settlement offer. For example, Plaintiff X alleges that a sporting food product manufactured by ABC Sporting Goods Manufacturing Company caused a catastrophic injury. Plaintiff X offers to settle for $\$ 1$ million. If $\mathrm{ABC}$ Sporting Goods refuses to settle and the court awards the plaintiff $\$ 2$ million, then $A B C$ Sporting Goods would be liable for damages amounting to $\$ 2$ million plus a maximum of $\$ 50,000$.

Senate Bill 687 imposed no monetary penalty on a plaintiff who refused to accept a defendant's settlement offer in order to protect the injured plaintiff's constitutional right to a trial by jury. However, if the defendant offers to settle and the plaintiff refuses, the plaintiff's award (if any) would be reduced by the collateral benefits claimant has received or is entitled to receive. For example, a $\$ 1$ million dollar judgment would be reduced by any worker compensation payments or insurance monies the plaintiff has received. This measure ensures faimess as plaintiffs do not receive "double "relief at a manufacturer's expense. 


\section{ALTERNATIVES DISPUTE RESOLUTION (ADR)}

ADR allows both parties to avoid the adversarial, win-loss outcome associated with the judicial system. As stated by Glenn (1987),

Cases are settled by means of compromise rather than adjudication because, rightly or wrongly, both parties perceive their interests as being best served by avoiding court. This is the essence of compromise: the willingness of the parties to give ground in order to achieve limited gains, rather than to pursue complete success and in so doing take the risk of no gain, or worse, some palpable loss (p. 11).

Senate Bill 687 (S. Rep. No. 203, 103rd Gong., 1st Sess., Sec 102) retains the right of either party to partake in state approved alternative dispute resolution (ADR) procedures. Court-annexed arbitration laws existed in 24 states by the end of the 1980s (McIver and Keilitz, 1991). ADR benefits include provisions for small claim plaintiffs access to a remedial system, expedition of the decision process, and a reduction in number of cases before state courts. For example, ADR enables lowincome plaintiffs to pursue a rapid remedy without being subject to large expenses associated with expert witnesses and extensive discovery. Most ADR statutes qualify the time frame associated with the ADR process, the type of claim that can be submitted for ADR, as well as the available dollar amounts for recovery (McIver and Keilitz, 1991). Parties discontent with the resolution of an ADR proceeding are still guaranteed their constitutional right to a trial de nova before the courts if desired.

Similar penalties are imposed on the defendant who refuses to abide by the ADR outcome as those imposed on the defendant refusing to accept a plaintiff's offer to settle. Defendants would be liable for the plaintiff's reasonable attorney fees if the court determines that the decision of a defendant to re-litigate in the courts was "unreasonable or not in good faith" (Sec. 102 (b)(3)). In ascertaining whether a case was re-litigated "reasonably," Senate bill 687 states, "the court shall consider such factors as the court deems appropriate." The Committee on Commerce, Science and Transportation offers clarification of factors which would facilitate the court's effort to ascertain whether a refusal was "unreasonable" or exercised in "bad faith." The Committee encourages the courts to consider the following issues on a case-bycase basis when defendants decide to re-litigate ADR decisions and lose (S. Rep. No. 203, 103rd Cong., 1st Sess., Sec. 102 (b)(3), p. 36).

(1) Did the case involve complicated issues of fact? If so, ADR Procedures may not be appropriate as they intended for straightforward, less complicated cases.

(2) Does the case involve a potentially dispositive issue of law? In these cases, disposition depends on a ruling on the law, not a resolution of the factual issues.

(3) Is the case likely to be re-litigated or is there a lack of qualified arbitrators or mediators?

Plaintiffs, on the other hand, are not penalized for failing to accept the outcome of an ADR settlement. Again, similar to the above, a plaintiff loses all collateral payments if an offer is refused and the plaintiff is awarded a reduced amount at trial. 


\section{RESPONSIBILITY OF PRODUCT SELLERS}

Although only $5 \%$ of product sellers are actually held liable in product liability cases, they are frequently required to expend monies preparing a defense. This translates into an unnecessary expense that is ultimately passed on to the consumer. More alarming is the fact that 34 states currently treat product sellers as if they were an actual manufacturer. In other words, "they are absolutely liable for a manufacturer's mistakes" (Schwartz, 1993). The logic of holding product sellers liable as manufacturers is two-fold. First this argument assumes that the product sellers can exert buyer power on the manufacturer by demanding top quality products and refusing to sell products of a substandard quality. However, the demand associated with sporting goods equipment neutralizes this argument as buyers (i.e., retailers) often are forced to take what they can get in order to fill orders. Second, this logic assumes that all product sellers will have the monies and resources needed to seek indemnification from manufacturers. The fallacy of this argument is obvious as transaction cost, expended time of personnel, public relations problems, and diminished goodwill often devastate the net income generated by retailers.

Fred Juer, chair of the Sporting Goods Manufacturers Federal Agencies Committee, commented on a retailers liability at the 1977 Senate Subcommittee Hearings on Product Liability Insurance (Product Liability Insurance, 1977b). As stated by Juer, "A Columbus, Ohio sporting goods retailer was sued for $\$ 16$ million for selling a few helmets." (Product Liability Insurance, 1977b, p. 305). The company did not have insurance and was forced into bankruptcy. Juer refers to a Boston retailer as well. This retailer was more fortunate. The company was not forced into bankruptcy, but it did lose $\$ 120,000$ for selling 12 hockey helmets. As explained in the 1993 Committee Report, the current product liability system simply holds productive sellers liable "for product-related harms that they did not cause and over which they had no control" (Product Liability Insurance, 1977b, p. 37). as explained by Delbey Humphrey, the Chairman of the Board of Schutt Manufacturing Company, "dealers are now refusing to handle our product out of fear... as a result of excessive and unwarranted product liability suits" (Product Liability Reform, 1982b, p. 281).

Senate Bill 687 mitigates the problem of strict liability for retailers by imposing liability based upon fault only (with one exception). The Bill states that the product seller is liable when: (a) an express product warranty (oral or written) is made, (b) the product fails to conform to the express warranty, and (c) the failure to conform to the express warranty caused the injury (Congressional Record, Sec. 202(a)(2)(A)). This is similar to the familiar breach of fitness warranty and follows established case law precedent. For example, in Hauter v. Zogarts (1975) a product seller communicated to consumers via packaging that a particular golf training device was "completely safe" and "would not hit player." When a consumer was injured by the device the Supreme Court of California held the product seller liable for a number of reasons, one of which was the seller's breach of express warranty.

A product seller may also be liable if the seller does not exercise "reasonable care" in handling the product and this failure to exercise reasonable care is the proximate cause of the injury (Congressional Record, 1993, Sec. 202(a)(1)). For 
example, a sporting goods product seller may be responsible if it places a trampoline in the stream of commerce without the required literature (e.g., assembly instructions). in this scenario, the product seller may be liable if improper assembly is the proximate cause of an alleged injury. The proposed bill clearly states that product sellers remain liable when they fail to provide consumers with "any pamphlets, booklets, labels, inserts, or other written warning s or instructions received while the product was in the seller's possession and control" (Congressional Record, 1993, P. S4149). Further, product sellers are responsible for making a "reasonable effort: to provide consumers with product warnings and/or instructions received after the product has been sold (Congressional Record, 1993).

in both of the above situations, the product seller is liable for the consequences of his own acts. Plaintiff advocates, however, demand that some party be required to pay when a plaintiff has been injured by a particular product. Consequently, Senate Bill 687 (Congressional Record, 1993) does subject product sellers to liability if either the manufacturer is granted immunity via state laws or if "the court determines that the claimant would be unable to enforce a judgment against the manufacture" p. S4149). This departure from the doctrine of individual responsibility for harm ensures that a claimant can recover damages from someone. The sporting goods industry in general and sporting goods retailers in particular will likely be against Section 202(c) because it continues the rationalization that personal injuries should be borne by those who society believes can better bear the loss. As stated by Ruger at the 1980 Senate Hearings on Product Liability (Product Liability: Legislative Hearings 1980b),

Tort law is not a compensation system similar to social security or Worker Compensation ... product liability law should impose liability only where it is fair to deem the product seller responsible for an injury ( $p, 543$ ).

\section{PUNITIVE DAMAGES}

Punitive damages, originally awarded only for intentional torts, have generated a great deal of debate and dissension (Schwartz and Behrens, 1993). A primary issue of contention centers around the jury's unlimited discretion in awarding damages which has frequently resulted in extreme settlements against defendants. The following data compiled by RAND Corporation's Institute for Civil Justice is frequently cited to by reform advocates (Dunworth, 1988).

a) The average punitive damage award in Cook County increased in inflationadjusted dollars from $\$ 43,000$ in $1965-1969$ to $\$ 72900$ in $1980-1984-$ a 1,500 percent increase.

b) In San Francisco, the average punitive damage awards jumped from an average of $\$ 95,000$ in 1964-69 to $\$ 381,000$ in 1980-84-a 300 percent increase.

c) The average personal injury punitive damage award in Cook County increased from $\$ 14,000$ in $1965-69$ to $\$ 1,934,000$ in $1980-84-$ a 13,700 percent increase. 
d) Business/contract punitive damage awards in Cook County during the same period went from $\$ 97,000$ to $\$ 624,000$, a 543 percent increase in inflationadjusted dollars (p. 81, 102-727).

The Supreme Court recognized the unfair consequences of punitive damages in the 1991 case, Pacific Mutual Life Insurance Co. v. Haslip. In this case, punitive damages were four times greater than compensatory damages. Further, the punitive damages amounted to $\$ 840,000$, or 200 times the out-of-pocket expenses (less than $\$ 4,000$ ) of the plaintiff, Haslip. A similar award was given in Eichenseer v. Reserve Life Ins. Co. (1991). in this case, the plaintiff was awarded $\$ 500,000$ in punitive damages although the compensatory award mounted to only $\$ 1,000$. As stated by Twerski (1985, p. 611), "The inadvertent production defect case that occurs because of imperfect quality control rarely, if ever, involves that kind of reckless conduct that would support punitive damages." Punitive damage awards were non-existent in tort product liability cases until 1965. The occurrence of punitive damages increased in the mid-1970s and became relatively routine by the mid $1980 \mathrm{~s}$. Unrestrained punitive damage awards place American Businesses at a competitive disadvantage. Foreign competitors, for example, Great Britain, Canada, Japan, and Europe rarely (if ever) are subjected to punitive damages (Mahoney and Littlejohn, 1989; Nutter, 1988). The resultant benefits realized by foreign competitors include greater expense predictability, a lower cost structure, and more competitive prices.

Exorbitant punitive damages have been recently challenged under both the Eighth Amendment (Excessive Fines Clause) and the Fourteenth Amendments (denial of property without due process). However, courts continue to be reluctant to diverge from the established precedent and confine jury discretion. The Court's decision in Pacific Mutual Life Insurance Co. v. Haslip (1991) is an exception. In this case the Court recognized that punitive damages could violate due process in certain situations. As explained by the Court,

One must concede that unlimited jury discretion-or unlimited judicial discretion for that matter-in the fixing of punitive damages may invite extreme results that jar one's constitutional sensibilities... We need not, and indeed we cannot, draw a mathematical bright line between the constitutionally acceptable and the constitutionally unacceptable that would fit every case. We can say, however, that general concerns of reasonableness and adequate guidance from the court when the case is tried to a jury properly enter into the constitutional calculus (p. 1043).

Other courts, perhaps less concerned about jury reasonableness and the need for guidance, chose to leave constitutional calculus to legislators. Indeed, subsequent Supreme Court decisions (e.g., TXO Production Corp. v. Alliance Resources, Inc., 1992) failed to address the issue and instead recognized the need for legislative action to resolve punitive damage absurdities. only in the recent turmoil over extreme punitive damages in the BMW case has the Supreme Court chosen to act. In January 1995 the top court decided to revisit punitive damages in an appeal by $\mathrm{BMW}$ of a $\$ 2$ million punitive award in an Alabama consumer lawsuit (Barrett, 1995).

Many state legislators have attempted to abolish the inequities associated with large punitive damages. However, a state-by-state approach to punitive damage 
reform is problematic for two reasons. First, individual states cannot by themselves solve the problems associated with the diversity of state laws that manufacturers, engaged in interstate commerce, confront. As explained by Schwartz and Behrens (1993),

Vague and uncertain punitive damages law has a substantial and detrimental impact on American industry. Most troubling, uncertainty about how and when punitive damages awards will be imposed adversely affects the development of new technology (p. 1371).

The unpredictability forces manufacturers to lose competitive ground as R\&D efforts and product innovations are curtailed and monies are reserved for potential transaction and insurance expenses.

Second, state legislatures may be hesitant to pass punitive damage reform that precludes relief to in-state citizens by out-of-state manufacturers (Schwartz and Magarian, 1992). As explained by the court in Garnes v. Fleming Landfill, Inc. (1991),

Unchecked punitive damage awards can lead to a "competitive race to the bottom." The competitive race to the bottom is caused by the desire to "help your own."... Local juries and local courts naturally will favor local plaintiffs over out-of-state (often faceless, publicly held) corporations when awarding punitive damages. Inevitably, this race... leads to increasing efforts to redistribute wealth from without the state to within (p.906).

Senate Bill 687 does not prohibit punitive damages as advocated by some members of the sporting goods industry (Product Liability: Legislative Hearings, $1980 \mathrm{a}, 1980 \mathrm{~b}$ ). Nor does it place caps on the amount of punitive damages awarded. However, it does attempt to alleviate the inequities and problems associated with punitive damages in seven ways.

First, Senate Bill 687 adopts the "clear and convincing" evidence burden of proof. This standard is supported by the American Bar Association, the American College of Trial Lawyers, and the American Law Institute. In addition, approximately 25 states have adopted the clear and convincing standard by either legislative or judicial decree (Schwartz and Behrens, 1993). Colorado adopted an even more stringent standard of proof and requires that plaintiffs be allowed to recover punitive damages only when they have been able to meet the "beyond reasonable doubt" standard of evidence (Colo. Rev. Stat. Section 13-25-127(2) (Supp. 1979). Five states (LA, MA, NE, WA, NH) have statutory prohibitions regarding punitive damages awards. Senate Bill 867 would not have preempted those state laws.

Section 203(a) of Senate Bill 687 (Congressional Record, 1993) provides that punitive damages may be awarded only when the plaintiff,

Establishes by clear and convincing evidence that the harm suffered... was the result of conduct manifesting a manufacturer's or product seller's conscious, flagrant indifference to the safety of those persons who might be harmed by the product (p. S4149).

The clear and convincing standard of evidence falls between the standard of proof required in civil cases and the standard of proof required in criminal cases. In other words, the plaintiff must be able to meet a standard of proof somewhere between 
evidence which is merely "more convincing than the opponents" (i.e., beyond a preponderance of evidence) and evidence which is "clear, precise, and indubitable" (i.e., beyond a reasonable doubt). As explained in the committee's Report, the required burden of proof is "a standard of proof closer to the criminal law for imposing punishment" (Product Liability Fairness Act, 1993, p.40).

Second, Senate Bill 687 reduces the abuse associated with punitive damage awards by allowing punitive damages only when a manufacturer acted with "conscious, flagrant indifference" to the consumer (Congressional Record, 1993). As explained in the Committee's Report, punitive damages should be awarded only when the plaintiff can prove that the defendant's fault is "far in excess of mere negligence," and when conduct is "an extreme deviation from ordinary conduct." As explained by the Committee Report,

It is only when a manufacturer consciously leaves in its product a danger that is unreasonable, and sells the product to the public knowing it to be defective, that its conduct can be said to manifest a "conscious, flagrant indifference" to consumer safety (S. Rep. No. 203, 1993, 103rd Cong., 1st Sess., p. 44).

This language in Senate Bill 687 is somewhat vague as neither the bill, nor the Committee's interpretation, succinctly defines "an extreme deviation from ordinary conduct." In other words, state-by-state interpretation will dictate whether manufacturers are subject to liability for acts of gross negligence, reckless disregard, and/ or willful, wanton negligence; or, rather only acts qualify as willful, wanton will elicit a remedy. This portion of the proposed bill alters traditional negligence law which frequently awards punitive damages for negligent actions judged more egregious than the "ordinary" negligence standard.

Third, Section 203(a) of Senate Bill 687 exempts manufacturers from punitive damages liability when they fail to "exercise reasonable care in choosing among alternative product designs, formulations, instructions, or warnings." As further elaborated on in the Committee Report, the failure to "exercise reasonable care" is, by definition, merely negligent behavior falling below the proposed "flagrant indifference" standard.

Four, Section 203(a) of Senate Bill 687 prohibits the award of punitive damages "in the absence of any compensatory damages." This section of Senate Bill 687 echoes a recent 1992 Supreme Court of Appeals decision in Garnes v. Fleming Landfill, Inc. and judicial guidelines inferred from Pacific Mutual Life Ins. Co. v. Haslip., (1991); Green Oil Co. v. Hornsby, (1989); and Browning-Ferris Industries of Vermont, Inc. v. Kelco, (1989). As stated in a 1992 Supreme Court of Appeals decision,

Punitive damages should bear a reasonable relationship to the potential of harm caused by the defendant's actions and that generally means that punitive damages must bear a reasonable relationship to actual damages because compensatory damages provide a reasonable measure of harm (p. 908).

This section of Senate Bill 687 is strongly pro-business. in contrast, Ellis and others (1982) have argued that historically one of the principle motivations behind punitive damages is to punish a wrongdoer for those egregious acts which result in little, or difficult to assess, compensatory damages. Section 203 (a) prohibits large 
punitive awards when compensatory damages are insignificant or non-quantifiable.

Five, Senate Bill 687 (Sec. 203(b), 203(c)) prohibits the awarding of punitive damages when drug and aircraft or aircraft components meet industry safety standards. Jurors would be better able to both assess the conduct of the manufacturer and the resultant need for a punitive damage award when comparing product design defects with product design standards. Manufacturers complying with technologybased standards would not be liable for related product design injuries. The compliance with regulatory standard clause and related immunity is supported by the American Law Institute. As quoted in Schwartz and Behrens (1993),

We believe that the risk of over deterrence of socially valuable activities through the imposition of tort liability on regulated products and activities merits more widespread recognition of a regulatory compliance defense... The strongest case for a regulatory compliance defense arises when punitive damages are sought. If a defendant has fully complied with a regulatory requirement and fully disclosed all material information relating to risk and its control, it is hard to justify the jury's freedom to award punitive damages (p. 95, 101)

Senate Bill 687 does not specifically mention the sporting goods industry or its regulatory standards. SGMA members discussed the need for industry standards as early as 1964 (Burke, 1964, 1969b). Efforts to develop standards continued during the 1960s and early 1970s (Burke, 1969a,; Rust, 1970) Much of the impetus for the development of standards came from football helmet manufacturers (Wilkenson, 1970; Horton, 1971). An early Rawlings case, the 1972 Consumer Products Safety Act (Kimble, 1975), and President Nixon's Commission of Product Safety further motivated sporting goods manufactures (Burke, 1969a, 1969b: "Rawlings wins historic case," 1970; Wilkenson, 1970). Again, football helmets were a major concern (Horton, 1971). After nearly two years of study, the National Operation Committee for Standards in Athletic Equipment (NOCSAE) established minimum standards for football helmets in 1973 (Horton, 1971; "First findings," 1972; Sage, 1973; "Safety standards," 1973). NOCSAE's technology-based standards did not prevent punitive damages in cases against Riddell, Inc. (Stead v. Riddell, Inc., 1971, Galindo v. Riddell, 1982) even though Riddell's helmets met industry wide technology based standards. in each instance claimant's lawyers were able to produce alternative standards, established by non-sport standard committees, which Riddell helmets were unable to meet. The inclusion within a reform bill which absolved companies of punitive damage liability when products met industry and product related standards would mitigate the lottery-like system of punitive damages.

Six, Senate Bill 687 (Sec. 203(e)) adopts criteria for consideration used by courts when determining the reasonableness of punitive damages (Pacific Mutual Life Ins. Co. v. Haslip, 1991; Green Oil Co. v. Hornsby, 1989; Garnes v. Fleming Landfill, Inc., 1991). The proposed guidelines serve to eliminate the inconsistency and uncertainty accompanying jury decisions (Ellis, 1982). Justice O'Connor expressed support for such guidelines in a dissenting opinion. As explained by Justice O'Connor in Pacific Mutual (1991), 
Juries are permitted to target unpopular defendants, penalize unorthodox or controversial views, and redistribute wealth. Multimillion dollar losses are inflicted on a whim. While I do not question the general legitimacy of punitive damages, I see a strong need to provide juries with standards to constrain their discretion so that they may exercise their power wisely, not capriciously or maliciously. p 1056

S.B. 687 provides juries guidance and direction when ascertaining the amount of punitive damages to be awarded if a jury does determine that he manufacturer should be subjected to punitive damages. As stated in Section 203(e),

The trier of fact shall consider all relevant evidence including -

(1) the financial condition of the manufacturer or product seller;

(2) the severity of the harm caused by the conduct of the manufacturer or product seller;

(3) the duration of the conduct or any concealment of it by the manufacturer or product seller;

(4) the profitability of the conduct to the manufacturer or product seller;

(5) the number of products sold by the manufacturer or product seller of the kind causing the harm complained of by the claimant;

(6) awards of punitive or exemplary damages to persons similarly situated to the claimant;

(7) prospective awards of compensatory damages to persons similarly situated to the claimant;

(8) any criminal penalties imposed on the manufacturer or product seller as a result of the conduct complained of by the claimant; and

(9) the amount of any civil fines assessed against the defendants a result of the conduct complained of by the claimant. p. S4149

Seven, Section 203(d) allows the defendant to request a separate proceeding on (a) whether punitive damages should be allowed and (b) the subsequent amount of the punitive damage award (if any). This provision reduces the likelihood that information regarding prior punitive awards, the defendant's financial condition, and profits made from wrongful activity will bias the jury's award for compensatory damages. This provision benefits sporting goods manufactures and juries cannot use evidence presented in the trial for compensatory damages (e.g., net worth of the company) in deciding punitive damage awards.

\section{UNIFORM TIME LIMITATIONS ON LIABILITY}

Current product liability laws greatly differ regarding the duration of time in which a plaintiff may sue. For example, the time limitations in some states begin to run form the "time of the injury." Consequently, a plaintiff may have no recourse if the injury has any lengthy latency period, or if the injury result from repeated exposure to the particular product. Time limitations in other states begin to run from the "time the injury is discovered." This standard also hinders a plaintiff's ability to recover as a plaintiff may recognize and injury but not know the cause of the particular injury until years later; after expiration of the regulatory allowed time. 
The ease of plaintiff recovery is now contingent upon state residency. Senate Bill 687 benefits the plaintiff, regardless of state residency, by adopting a uniform discovery rule. As stated in Section 104(a), plaintiffs have two years from the time of discovery, or "in the exercise of reasonable care, should have discovered the harm and its cause," to sue (p. S4150).

S.B. 687, Section 204(b) defines a 25 year statute of repose for capital goods (toxic harms are exempted) which injure a claimant regardless of discovery of harm and cause. A statute of limitations is needed, proponents argue, as products with longevity may cause injuries years after manufacture. Manufacturers should not be responsible for products which have been poorly maintained, abused, or altered. Upon expiration of the 25 years, manufacturers may no longer be held liable when capital products cause injury. The National Tool Builders' Association stated in the 1987 Hearing that $37 \%$ of all claims could be eliminated with the adaptation of a 25 year statute of repose (Product Liability, 1987b). Section 204(b) only applies to those situations in which the claimant is able to receive worker's compensation benefits. This provision is important for the injured as it is estimated that approximately $90 \%$ of the U.S. labor force is covered by worker compensation statutes. Workers injured after the 25 year period, although banned from suing the manufacturer, would find recourse via workers compensation. Sixteen states currently have some type of statue of repose. In fact, the existing statures of repose in 15 of the states apply to all products and are not limited to capital goods (Committee Report, 1993). Section (204 (b)(3)(A) defines a "capital good" as,

Any product, or any component of any such product, which is of a character subject to allowance for depreciation under the Internal Revenue Code of 1986, and which was -(i) used in a trade or business; (ii) held for the production of income; or (iii) sold or donated to a governmental or private entity for the production of goods for training, for demonstration, or for other similar purposes... p. $\$ 4150$

Current product liability law imposes unreasonable hardships on manufacturers as they remain responsible for injuries caused by capital goods for, in some instances, an indefinite time period. The statute of repose is logical for two reasons. First, it seems logical that the "usablity" of capital goods should coincide with depreciation figures provided by the IRS. Second, the absence of a reasonable statute of repose places American manufacturers at a competitive disadvantage in comparison to foreign counterparts. As recognized by Schwartz (1993), there are not many cases involving product (i.e., machinery) over the age of 25 years in which the defendant does not win. However, the transaction and insurance costs associated with this equipment is much higher than foreign competitors entering established markets.

Sporting Arms \& Ammunition Manufacturers' Institute (Product Liability Act, 1983) argued that a statute or repose should exist for all consumer products. As argued by the SAMI, "Many consumer goods are extremely durable, equally if not longer lasting than capital goods. That is certainly true with firearms." Similarly, Sturm, Rugers, a firearm manufacturer, argues that the statute of repose should be less than 10 years (Product Liability; Legislative Hearings, 1980b, p. 554). Section 204(b) of Senate Bill 687, however, is not so radical. The statute of repose will have a trickle down effect on manufactures of sporting goods as well as the end user. For 
example, the uncertainty of the current product liability system forces suppliers of sporting goods machining equipment to pad their expense structure with potential liability expenses. These real and potential expenses are then passed down to the sporting goods manufacture and throughout the entire distribution chain. The statute of repose will mitigate the expenses related with unreasonable capital good litigation and improve the cost structure of all involved.

\section{SEVERAL LIABILITY FOR NON-ECONOMIC LOSS}

Joint and several liability is another doctrine which has been long contested by manufactures (Fox, 1988). Joint and several liability originally only applied only when parties had actually conspired to harm an individual or when they pursued actions which were "likely" to result in a person's injury. However, the evolved interpretation and application of joint and several liability imposes liability for the entire damage amount on all or any one defendant(s) regardless of contributed fault or conspiracy involvement. The common referred to "deep pocket mentality" reflect this evolved concept of joint and several liability. As explained by Fox (1988),

Obviously, it is in the injured person's interest to sue a manufacturer with significant assets, no matter how slight the manufacturer's involvement in the injury, and seek substantial damages. Under such conditions, corporations, on the advice of their insurers, are likely to pay out-of-court settlements to avoid legal costs and potential high awards, encouraging, critics charge, additional suits.

Senate Bill 687 mitigates the inequities associated with the joint and several liability doctrine by stating that a defendant will be liable for non-economic damages only proportionate to fault. Numerous states have already abolished or modified the joint and several liability doctrine due to the resultant inequities (Committee Report, 1993). Senate Bill 687, which places no limits on compensatory damages, would not preempt state laws addressing joint and several liability as applied to either economic or non-economic damages.

\section{DEFENSE INVOLVING INTOXICATING ALCOHOL OR DRUGS}

Schwartz's research indicates that "in about 13 states people can recover in product liability actions even though a substantial cause of an accident was the fact that the claimant was inebriated or under the influence of illegal drugs" (Product Liability Fairness Act, 19933, p. 64). Senate Bill 687 relieves the manufacture of all liability when a plaintiff under the influence of alcohol or a drug(s) is injured while using a product if the intoxication was more then $50 \%$ responsible for the plaintiff's harm. The assumption implicit in this section of the bill is that if the plaintiff had not been under the influence of alcohol or a drug(s) while using a manufacturer's product, no harm would have likely occurred. Section 207(c) states that the applicable state law will be referred to when determining whether a person was intoxicated.

As defined by the Senate Bill (Section 207(d)), a drug is "any non-over-thecounter drug which has not been prescribed by a physician for use by the claimant" (p. S44151). This section of the Product Liability Fairness Act raises the issue of 
whether, for example, sporting goods equipment manufacturers would be liable if evidence concluded that the plaintiff- or defendant-athlete, equipped with the sporting goods equipment, was on steroids at the time of the injury. For example, this section of the bill may allow a football helmet manufacturer to argue that a football player was in a steroid rage when he used the helmet in some fashion which caused injury. The reported steroid rage and mind alteration effects could be used to support the football helmet manufacturer's defense when plaintiff-athlete steroid users undergo catastrophic injuries.

\section{- SUMMARY}

The current product liability crisis has generated extensive debate regarding product liability reform. Editorials suggest that if product liability reform is ever going to be passed by Congress, the time is now (Barret, 1995; Geyelin \& Schmitt, 1994). As stated by Geyelin and Schmitt (1994, p. B5). "Chances of success appear vastly improved because several powerful Democrats who were able to stymie earlier efforts are either not returning to Congress or won't wield the clout they once did."

Many issues within Senate Bill 687 are replicated in the Contract with America and present reform efforts. Similar reform issues include the elimination of joint and several liability for non-economic damages and the mitigation or elimination of liability when alcohol or drugs contribute to an injury. However, the recent bill is much more pro-defendant than Senate Bill 687. For example, Senate Bill 687 makes no attempt to limit the amount of awarded punitive damages. In contrast, the present bill being considered by the Senate would cap punitive damages at three times the amount of compensatory damages, or $\$ 250,000$, whichever is greater. Similarly, Senate Bill 687 defines a 25 year statute of repose whereas the 1995 bill proposes a 15 year statute of repose. The "loser pays" concept, a companion bill referred to as the Attorney Accountability Act of 1995, is also more harsh and imposes a greater burden on the plaintiff-consumer.

Each of the above pro-defendant changes make the present product liability reform legislation less palatable to consumers than Senate Bill 687 as discussed in this essay. The present product liability system needs to be altered. The judicial imposition of strict liability forces manufactures to pay whether guilty or not. This social justice concept of risk distribution means manufactures pay regardless of fault. The current liability system increases transaction costs, raises insurance premiums, stifles product innovation, delays research and development, and causes high demand products to be withdrawn from the market. Excessive punitive damage awards change punishment to revenge. American companies compete at a disadvantage with foreign manufactures. The present product liability system varies among the 50 states. A uniform law is needed. Consumers need to be protected by so do sporting goods manufacturers. A balance of interests needs to be established. 


\section{References}

Barrett, P.M. (1995, March 9). How a bad pain job may put brakes on big punitive awards. The Wall Street Journal, pp. B1. B10.

Browning-Ferris Industries of Vermont, Inc. v. Kelco Disposal, Inc., 492 U.S. 257 (1989).

Burke, R. (1969a). AGMA warned of ambulance chasers. Sporting Goods Dealer, $140(2), 17$.

Burke, R. (1964). Riddell strict standards. Sporting Goods Dealer, 141(2), 81, 146.

Cantu, C.E. (1993). Twenty-five years of strict product liability law: The transformation and present meaning of Section 402A. St. Mary's Law Journal, 25(1), 327-353.

Castle, K. (1989, September). Liability woes threaten sports manufacturers. San Francisco Chronicle, p. E2.

Congressional Record, 103rd Congress, March 31, 1993.

Dart, B. (1989). Suits could mean end of high school football. The Palm Beach Post. Thursday, October 12 th. p?

Dunworth, T. (1988). Product liability and the business sector: Litigation trends in federal courts. Washington, D.C.: National Institute of Justice.

Eichenseerv. Reserve Life Ins. Co., 934 F2d 1377 (5th Cir. 1991).

Ellis D.D. (1982). Fairness and deficiency in the law of punitive damages. Southern California Law Review, 56(1), 1-78.

Escola v. Coca Cola Bottling Co. of Fresno, 150 P. 2d 436 1944).

Everett, C.A. (1989). The liability crisis: No risk, no sports, no fun. Trilogy, Fall/ Winter, 88-91.

First findings unveiled in probe of helmet safety (1972). Sporting Goods Dealer, I45(3), 134, 145.

Florio, J.J. (1983). Product liability, insurance, and the new federalism. Journal of Products law, 2(1/2), 1-19.

Fox, T.M. (1988, August). The lawsuit lottery. St. Petersburg Times.

Galindo v. Riddell, Inc. 437 N.E.2d 376 (Ill. App. 1982)

Garnes v. Flaming landfill, Inc., 413 S.E. 2d 897 (W.Va. 1991)

Garrett, M.C. (1972). Allowance of punitive damages in product liability claims. Georgia Law Review, 6, 613-630. 
Geyelin, M. and Schmitt, R.B. (1994, Nov. 11). Advocates of liability reform are upbeat after GOP landslide. The Wall Street Journal, p. B5.

Gillespie, E.G. and Schellhas, B. (Eds.) (1994). Contract with America. New York, NY: Times Books.

Glenn, H. (1987). Hard Bargaining. New York: Oxford University Press.

Goldman, G. (1976a). Conference, hearing probe product liability problem. Sporting Goods Dealer, 153(1), 47-56.

Goldman, G. (1976b). Panel probes liability issue at special AGMA session. Sporting Goods Dealer, 153(3), 50-52.

Goulian, L. (1988, July). The murderer of invention. Sports Inc., p.?.

Green Oil Co. v. Hornsby, 539 So. 2d 218 (Ala. 1989).

Greenman v. Yuba Power Products, Inc., 377 P. 2d 897 (1962).

Hauter v. Zogarts, 534 P. 2d 377 (1975).

Hay, B.L. (1992). Conflicts of law and state competition in the product liability system. The Georgetown Law Journal, 80(3), 617-652.

Henningsen v. Bloomfield Motors, Inc., 161 A.2d 69 (1960).

Horton, R. (1971). report on AGMA safety standards. Sporting Goods Dealer, I44(2), 58-59.

Howard, P.K. (1994). The Death of Common Sense. New York, NY: Random House, Inc.

Jeanblanc, L.R. (1937). Manufacturers; liability to persons other than their immediate vendees. Virginia Law Review, 24(2), 134-37.

Kessler, F. (1943). Contracts of adhesion: Some thoughts about freedom of contract. Columbia Law Review, 43(5), 629-642.

Kimble, W. (1975). Federal Consumer Product Safety Act. St. Paul: West Publishing.

Kotlowski, B. (May, 1988). PLS fights torts in sports: "Hardball" style. Defense Law News. pp. 1, 4.

Litan, R.E. (1991). The liability explosion and American trade performance: Myths and realities. In P.H. Schuck (Ed.). Tort Law and the Public Interest (pp. 127-150). NY, NY: W.W. Nortong \& Co., Inc.

Mahoney, R.J. and Littlejohn, S.E. (1989). Innovation on trial: Punitive damages versus new products. Science, 246, 1395-1399. 
MacPherson v. Buick Motor Co., 111 N.E. 1050, 1916.

Maxfield, C.J. (1982). Risk Retention Act: An alternative form of product liability insurance for small business. Federation if Insurance Counsel Quarterly, 32(3), 273-287.

McHugh, P. (1989, July). Risk liability: We've got the "Sue me, Sue you blues." Outdoor Retailer, pp. 32-33.

McIver, J.P. and Keilitz, S. (1991). court-annexed arbitration: An introduction. The Justice System Joumal, 14(2), 123-132.

Nader, R. (1972). Unsafe At Any Speed: The Designed-in Dangers of the American Automobile. New York, NY: Grossman.

Nutter, F.W. (September, 1988). Tipping the scales against us. Best's Review, pp. 28-34.

O’Brien v. Muskin Corporation, 463 A.2d 298 (N.J. 1983).

Pacific Mutual Life Insurance Company v. Haslip, 111 S. Ct. 1032 (1991).

Plant, M.L. (1957). Strict liability of manufacturers for injuries caused by defects in products-An opposing view. Tennessee Law Review, 24(7), 938-951.

Priest, G.L. (1987). The current insurance crisis and modern tort law. The Yale Law Journal, 96(6), 1521-1590.

Priest, G.L. (1985). The invention of enterprise liability: A critical history of the intellectual foundations of modern tort law. The Journal of Legal Studies, I4(3), 461-527.

Printing and Numerical Registering Co. v. Sampson, L.R. 19 Eq. 462, 465 (1875).

Product Liability, 1987: Hearing Before the Subcommittee on Commerce, Consumer Protection, and Competitiveness of the House of Representatives Committee on Energy and Commerce, 100th Cong., 1st Sess., (1987).

Product Liability, 1987a: Hearings Before the Subcommittee on Commerce, Consumer Protection, and Competitiveness of the House of Representatives Committee on Energy and Commerce, 100th Cong., 1 st Sess., (1987) (Testimony of Honorable Frank S. Swain, Chief Counsel for Advocacy, U.S. Small Business Administration).

Product Liability, 1987b: Hearings Before the Subcommittee on Commerce, Consumer Protection, and Competitiveness of the House of Representatives Committee on Energy and Commerce, 100th Cong., 1st Sess., (1987) (Testimony of James H. Maek, Public Affairs Director, Machine Tool Builders Association). 
Product Liability Act, 1983: Hearings Before the Subcommittee on the Consumer of the Senate Committee on Commerce, Science, and Transportation, 98th Cong., 1st Sess., (1983). (Statement of the Sporting Arms and Ammunition Manufacturers Association).

Product Liability Act, 1985: Hearings on S. 100 Before the Subcommittee on the Consumer of the Senate Committee on Commerce, Science, and Transportation, 99th Cong., 1st Sess., (1985). (Letter to Hon. Robert W. Kasten, Jr. from Maria Dennison, Director, SGMA, Washington Operations).

Product Liability Act Amendments, 1985: Hearings Before the Subcommittee on the Consumer of the Senate Committee on Commerce, Science, and Transportation, 99th Cong., 1st Sess., (1985). (Statement of Howard Bruns, President, SGMA).

Product Liability Fairness Act, 1993a: Hearings on S. 687 Before the Subcomm. on Consumer of the Committee on Commerce, Science, and Transportation, 103rd Cong., 1st Sess., (1993). (Statement of Julie Nimmons, CEO, Schutt Sports Group).

Product Liability Fairness Act, 1993b: Hearings on S. 687 Before the Subcomm. on Consumer of the Committee on Commerce, Science, and Transportation, 103rd Cong., 1st Sess., (1993). (Statement of Hon. Joseph T. Leiberman, U.S. Senator from Conn.).

Product Liability Fairness Act, 1993c: Hearings on S. 687 Before the Subcomm. on Consumer of the Committee on Commerce, Science, and Transportation, 103rd Cong., 1 st Sess., (1993). (Statement of L. Vincent, Chair and CEO, Biogen, Inc.).

Product Liability Fairness Act, 1993d: Hearings on S. 687 Before the Subcomm. on Consumer of the Committee on Commerce, Science, and Transportation, 103rd Cong., 1st Sess., (1993). (Statement by Senator Gordon).

Product Liability Fairness Act, 1993e: Hearings on S. 687 Before the Subcomm. on Consumer of the Committee on Commerce, Science, and Transportation, 103rd Cong., 1st Sess., (1993). (Statement of Judge Richard Neeley).

Product Liability Insurance, 1977a: Hearings Before the Subcommittee on Consumer of the Senate Committee on Commerce, Science, and Transportation, 95th Cong., 1st Sess., (1977). (Statement of Paul Benke, v. .P., AMF Marine Products Group).

Product Liability Insurance, 1977b: Hearings Before the Subcommittee on Consumer of the Senate Committee on Commerce, Science, and Transportation, 95th Cong., 1st Sess., (1977). (Statement of Fred Juer, on behalf of the MAAC). 
Product Liability Insurance, 1977c: Hearings Before the Subcommittee on Consumer of the Senate Committee on Commerce, Science, and Transportation, 95th Cong., 1st Sess., (1977). (Statement of William Bruns, President, SGMA).

Product Liability: Legislative Hearings, 1980a: Hearings Before the Subcommittee on Consumer Protection and Finance of the House of Representatives Committee on Interstate and Foreign Commerce, 96th Cong, 1st Sess., (1980). (Statement of Thomas L. Anderson, BMA representative).

Product Liability: Legislative Hearings, 1980b: Hearings Before the Subcommittee on Consumer Protection and Finance of the House of Representatives Committee on Interstate and Foreign Commerce, 96th Cong., 1st Sess., (1980). (Statement of William B. Ruger, Sr., President and Chair, Strum, Ruger \& Company).

Product Liability Reform, 1982a: Hearings on S. 2631 Before the Subcommittee for Consumers of the Committee on Commerce, Science, and Transportation, 97th Cong., 2nd Sess., (1982). (Statement of Maria Dennison, Director, Washington Operations, SGMA).

Product Liability Reform, 1982b: Hearings on S. 2631 Before the Subcommittee for Consumers of the Committee on Commerce, Science, and Transportation, 97th Cong., 2nd Sess., (1982). (Statement of Delby Humphrey, Chair of the Board, Schutt Manufacturing Company).

Product Liability Reform Act, 1990: Hearings on S. 1400 Before the Subcommittee on the Consumers of the Committee on Commerce, Science, and Transportation, 101st Cong., 2nd Sess., (1990).

Prosser, W.L. (1941). Handbook of the Law of Torts. St. Paul, MN: West Publishing Company.

Rust, D. (1970). Lawyer reviews Rawling's helmet victory: Bill of rights for American football. Sporting Goods Dealer, 143(6), 97-99.

S. Rep. No. 103-203, 103rd Cong., 1st Sess. (1993).

S. 687, 103rd Cong., 1st Sess., (1993).

S. Rep. No. 203, 103rd Cong., 1st Sess., (1993).

Safety standards for football helmets proposed (1973). Sporting Goods Dealer, 148(2), 164-165.

Sage, R. (1973). Manufacturers focus on product standards. Sporting Goods Dealer, $147(3), 52-55,57$.

Sanderfoot, A.E. (1989). Artificial wall brings climbing to new heights, though 
liability suits loom. Sporting Goods Business.

Schloerb, R.G., Blatt, R.N., Hammersfahr, R. W. \& Nugent, L.S. (1988). Punitive Damages: A Guide to the Insurability of Punitive Damages in the U.S. and Its Territories, Chicago, IL: Peterson, Ross, Schloerb \& Seidel.

Schwartz, V. E. (1993). Product Liability Fairness Act, S. 687. Journal of Products \& Toxics Liability, 15(4), 267-277.

Schwartz, V. E. and Behrens, M.A. (1993). Punitive damages reform: State legislatures can and should beet the challenge issued by the Supreme Court of the United States in Haslip. The American University Law Review, 42(4), 1365-1391.

Schwartz, V.E. and Magarian, L. (1992). Multiple punitive damage awards in mass disaster and product liability litigation: An assault on due process. Adelphia Law Journal, 8, 101-117.

Stead v. Riddell, Inc. Claim No: 01078726771 55, D/A: September 30, 1971.

Traynor, R.J. (1965). The ways and means of defective products and strict liability. Tennessee Law Review, 32(3), 363-377.

Twerski, A.D. (1985), A moderate and restrained federal product liability bill: Targeting the crisis areas for resolution. Journal of Law Reform, 18(3), 575-638.

TXO Production Corp. v. Alliance Resources, Inc., 419 S.E. 2d 870 (W.Va 1992).

White, G.E. (1985). Tort Law in America: An Intellectual History. NY, NY: Oxford University Press.

Wilkenson, J.H. (1970). College views of helmet controversy. Sporting Goods Dealer, $143(3), 59,64$.

Winterbottom v. Wright, 10 M. \& W. 112

\section{Endnotes}

1. The BMW case has attracted much interest from business advocates concerned about high damage awards. In 1994 the Supreme Court lowered a punitive damage award but reversal was based upon narrow procedural grounds (Barrett, 1995).

2. BMW lawyers hope to persuade the justices to define when punitive damage amounts are excessive and violate a defendant's constitutional right to due process. The Supreme Court had been in the past reluctant to do this. 